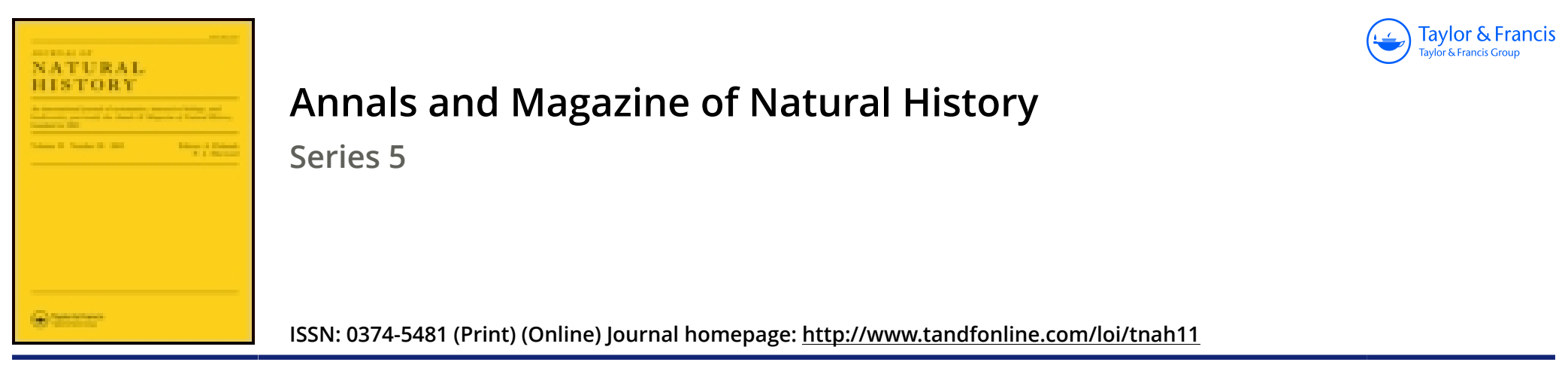

\title{
Addendum to our knowledge of the Carnosa
}

\section{H.J. Carter F.R.S.}

To cite this article: H.J. Carter F.R.S. (1881) Addendum to our knowledge of the Carnosa, Annals and Magazine of Natural History, 8:48, 450-450, DOI: 10.1080/00222938109487491

To link to this article: http://dx.doi.org/10.1080/00222938109487491

册 Published online: 09 Oct 2009.

Submit your article to this journal 준

LII Article views: 1

Q View related articles $\asymp$ 
winter. It is then covered by an inner shell, ornamented and formed of parchment cells. At the end of the winter this latter shell generally alone remains; and towards the month of March or April there issues from it a small but perfectly formed Melicerta, which does not pass through the phase of ciliated and swimming larva, like that born from the summer-egg.

Male Summer-Egg. - The development of the male egg is similar to that of the female summer-egg, at least up the closure of the blastopore. The creature that issues from it is about half the size of the female larva. It resembles the latter in general form, but differs in the complete absence of the digestive tube, and in the presence of an organ which, from the analogy of the male of Lacinularia, I regard as a sperm-sac, although I have been unable to detect in it any spermatozoids, but at the utmost some mother cells. This may be because I have always observed the male soon after exclusion. I have therefore no observation upon its function. It is rare, and dies soon; I have never found it in any tube of the female. Does it fertilize all the females, or only those with winter-eggs? Does it fertilize some of them, as is the case with certain species of insects? or is the reproduction wholly parthenogenetic? I cannot decide this. At any rate, I have never observed in any female any thing resembling a spermatozoid. The ovum, from the time of its passing into the sac of maturation, becomes clothed with a thick chorion; it always begins segmentation immediately after deposition, and apparently under the influence of water; for an ovum ready for deposition which remains in a dead female is not segmented, but becomes destroyed-that is to say, unless the chitinous envelope of the mother is torn so as to allow the water to enter, in which case the ovum soon begins its development,_Comptes Rendus, November 7, 1881, p. 748.

\section{Addendum to our Knowledge of the Carnosa. By H. J. CarTer, F.R.S. \&c.}

In the number of the 'Annals' for October last I gave a tabular view of the Carnosa (pp. 252, 253), omitting Lacinia stellifica, Salenka (p. 249) and Cellulophana pileata, Schmidt (p. 258), because I could not satisfy myself that they not only were not Carnosa, but not sponges at all.

Since then my attention has been called to Dr. F. E. Schultze's observations on his family "Chondrosidæ" (Zeitschrift f. wiss. Zoologie,Bd.xxix. 1877), wherein, at pp. 35 and 37 respectively, my doubts regarding the spongeous nature of these organisms are confirmed, inasmuch as Dr. Schultze therein affirms that he has satisfied himself, through actual examination, that both Lacinia stellifica and Cellulophana pileata are compound Ascidians.

I am not sorry that these recorded facts had slipped my memory at the time the "Contribution" to which I have alluded was compiled, because the observations therein made lead independently to the decisions of an unquestionable authority. 